\title{
(Re)estruturação das cidades médias do Sul de Minas Gerais: uma análise morfofuncional comparativa de Alfenas e Poços de Caldas
}

\author{
(Re)structuring of medium-sized cities in the South of Minas Gerais: a comparative \\ morphofunctional analysis of Alfenas and Poços de Caldas
}

\author{
Evânio dos Santos Branquinho \\ Doutor em Geografia e docente do \\ Programa de Pós-Graduação em Geografia da \\ Universidade Federal de Alfenas - MG, Brasil \\ evanio.branquinho@unifal-mg.edu.br \\ Eduardo de Araujo da Silva \\ Mestre em Geografia pelo \\ Programa de Pós-Graduação em Geografia da \\ Universidade Federal de Alfenas - MG, Brasil \\ eduardosilva.geografia@gmail.com
}

\begin{abstract}
Resumo
O presente estudo tem como proposta principal realizar uma análise morfofuncional comparativa entre as cidades médias de Alfenas e Poços de Caldas, ambas localizadas na mesorregião Sul/Sudoeste de Minas Gerais. Nesse sentido, para tal análise, consideramos a situação dessas cidades na rede urbana no sul de Minas Gerais e a relação com os espaços intraurbanos dessas cidades, tendo como contextos os processos de acumulação flexível, de reestruturação produtiva e da rede urbana no país, apontando para padrões espaciais mais complexos nas escalas regionais e locais. De modo geral, essas cidades médias apresentaram nas últimas décadas índices elevados de crescimento em função da desconcentração de atividades econômicas e população de grandes centros, advindo daí os problemas desse crescimento. Metodologicamente se colocam as dificuldades de comparar cidades, cada qual com suas especificidades geográficas e históricas, sem cair em generalizações e formalismos. A proposição foi, a partir da morfologia urbana, buscar as articulações entre as escalas regional e intraurbana, as relações regionais entre Poços de Caldas e Alfenas, visto que a primeira polariza a segunda, e estão em estágios diferenciados de evolução e estruturação urbana, conforme pode-se notar nos processos de dispersão e de fragmentação da mancha urbana e, portanto, os processos de produção do espaço, a dinâmica dos agentes e classes sociais, e da segregação socioespacial.
\end{abstract}

Palavras-chave: Espaço intraurbano; Rede urbana; Reestruturação da cidade.

\begin{abstract}
The main purpose of this study is to make a comparative morphofunctional analysis between the medium cities of Alfenas and Poços de Caldas, both located in the South/Southwestern region of Minas Gerais. In this sense, for such analysis, we consider the situation of these cities in the urban network in the south of Minas Gerais and the relationship with the intra-urban spaces of these cities, having as contexts the processes of flexible accumulation, productive restructuring and the urban network in the country, pointing out for more complex spatial patterns at regional and local scales. In general, these medium-sized cities showed high growth rates in recent decades due to the deconcentration of economic activities and population in large centres, resulting in the problems of this growth. However, methodologically, there are difficulties in comparing cities, each with its geographical and historical specificities, without generalizations and formalisms. Therefore, from
\end{abstract}


the urban morphology, the proposition was to seek the articulations between the regional and intraurban scales, the regional relations between Poços de Caldas and Alfenas, since the first polarize the second. They are in different stages of evolution and urban structuring, as can be seen in the processes of dispersion and fragmentation of the urban sprawl and, therefore, the processes of production of space, the dynamics of agents and social classes, and socio-spatial segregation.

Keywords: Intra-urban space; Urban network; City restructuring.

\section{INTRODUÇÃO}

Este trabalho tem como escopo principal analisar e comparar as transformações em termos de estruturação e reestruturação dos espaços urbanos das cidades médias, em suas particularidades e semelhanças, articulando a uma análise da rede urbana, tomando como estudos de caso as cidades de Alfenas e Poços de Caldas, localizadas na mesorregião Sul/Sudoeste de Minas Gerais. A análise comparativa visa compreender alguns padrões em relação à forma, estrutura e função dessas cidades.

As desigualdades na região se acentuaram, em função das diferentes potencialidades e vantagens que cada uma dessas cidades pode oferecer aos investimentos nacionais e transnacionais. No contexto de reestruturação produtiva, verifica-se uma reestruturação da rede urbana, com uma maior divisão territorial do trabalho e, portanto, especialização das cidades.

No âmbito do espaço intra-urbano, essas cidades também passaram por significativas transformações (reestruturação). Novas infraestruturas e equipamentos coletivos são instalados para abrigar empresas e população, tais como: rede viária, distritos industriais, hipermercados, shopping centers, condomínios fechados, conjuntos habitacionais, etc., indicando, em escala local e em suas particularidades, modos de reprodução do espaço urbano de grandes cidades e/ou um movimento desses capitais em direção a esses novos mercados, como incorporadoras, construtoras, redes de lojas.

Nesse arranjo mais complexo, observa-se a intensificação da fragmentação do espaço urbano, seja pelos processos de segregação socioespacial, ou pela expansão do tecido urbano, a exemplo dos condomínios fechados, distritos industriais e desconcentração de grandes equipamentos urbanos.

Embora classificadas como "cidades médias”, ambas apresentam estágios diferenciados de produção do espaço urbano. Alfenas está num estágio mais incipiente enquanto Poços de Caldas em uma fase mais avançada, o que reflete em posições diferentes na hierarquia da rede urbana. Por seu turno, Poços de Caldas estabelece uma polarização regional mais ampla, e pode ser evidenciada, por exemplo, na escala intra-urbana, em relação às áreas centrais, dispersão da mancha urbana, níveis de segregação socioespacial e articulação aos espaços rurais. 
Os procedimentos metodológicos são apoiados em pesquisa bibliográfica de livros, artigos e teses referentes aos temas de Geografia Urbana e, particularmente, os que envolvem as cidades de Alfenas e Poços de Caldas e seus quadros correlatos; levantamento de dados estatísticos em órgãos institucionais; levantamento cartográfico; e registro fotográfico e descritivo em trabalhos de campo.

\section{FUNDAMENTOS TEÓRICOS}

Cabe indagar se é válida a comparação entre cidades, em função de suas especificidades geográficas e seus processos históricos que são únicos. Se alguma generalização é possível, e em que termos essa comparação poderia ser feita, levando-se em consideração os aspectos de forma, estrutura e função? E, particularmente, no caso de Alfenas, uma cidade média em consolidação, e Poços de Caldas, uma cidade média consolidada, ambas localizadas na mesorregião sul/sudoeste de Minas Gerais?

Villaça (2001) aponta alguns equívocos de análises comparativas entre as cidades, neste caso em um artigo publicado, acerca de Buenos Aires, Santiago do Chile e Lima:

Isso se manifesta no fato de adotarem, para a história do espaço intra-urbano, a mesma periodização e as mesmas etapas que adotam para o desenvolvimento nacional. Tem-se aqui um exemplo da indevida transposição, para a análise intra-urbana, de premissas e métodos válidos para o estudo do desenvolvimento nacional. A premissa seria válida se, na melhor das hipóteses, o objeto de análise fosse o processo de urbanização, mas não outro diferente - o de estruturação intra-urbana (VILLAÇA, 2001, p. 34).

Azais (2006, p. 310), em um artigo comparando as cidades de Santo André, localizada na região metropolitana de São Paulo, e Saint Denis, na região metropolitana de Paris, e diante das grandes diferenças entre essas duas cidades, argumenta em termos metodológicos que:

A priori, a comparação entre as duas cidades escolhidas poderia parecer difícil de se sustentar; no entanto, é justamente pelo seu caráter contrastado que ela adquire certa relevância. A metodologia do MDSD (Most Diffferent Systemas Design), ou seja, a comparação dos casos mais contrastantes remete a uma estratégia conhecida na comparação em Ciências Sociais. Analisar a emergência de um fenômeno único, porém complexo, em contextos de emergência contrastantes, permite destacar fatores explicativos originais e mostrar embates de coerência societal, próprios de cada país.

Embora a pesquisa do autor seja referente às instituições administrativas e das formas de participação da população das cidades referidas, chega a conclusões importantes:

\footnotetext{
Sem pretender ter chegado a uma comparação entre ambas, o que se quis salientar foi o fato de que fenômenos aparentemente semelhantes podiam chegar a resultados diferentes quando processados. O tempo das instituições, das organizações e dos atores locais não é idêntico (AZAIS, 2006, p. 323).
}

Não obstante, nos estudos geográficos, temos a tendência de levar mais em consideração as escalas espaciais, no caso de uma análise comparativa entre cidades, as quais possuem tempos de estruturação diferentes, também é fundamental considerar as escalas temporais distintas em seus processos de estruturação urbana. 
Uma vez que essas cidades não estão em áreas metropolitanas, uma questão importante é compreender como elas polarizam a sua região de influência, mas também como elas próprias são polarizadas. A partir daí, busca-se uma caracterização dessas redes urbanas e a organização interna das cidades em estudo.

Portanto, esta pesquisa tem como eixo metodológico principal a articulação entre as escalas geográficas regional e intra-urbana, não desconsiderando as escalas internacional e nacional. Uma vez que a análise de cidades médias implica diretamente no seu papel regional, procura-se entender como estas cidades se condicionam/organizam em seu espaço intra-urbano para exercer uma polarização regional.

As interações espaciais das escalas articulam-se a uma totalidade - a globalidade social que carrega uma gênese e um movimento. Procuramos, assim, articular as partes da análise a um processo global de reprodução da sociedade como um todo. Isso vale também para a abordagem da cidade média, que pode ser entendida em sua dinâmica. Para Corrêa (2007, p. 26), “A cidade média pode ser, assim, como um estado transitório. As implicações disso podem ser amplas para mais o estabelecimento de um conceito de cidade média".

Acerca do conceito de cidade média, não nos aprofundaremos aqui, e apoiado no autor referido anteriormente, procura-se a classificação desta numa particular combinação entre tamanho demográfico, funções urbanas e organização do espaço intra-urbano. Expressando uma dialética entre quantidade e qualidade em que o tamanho da população resulta numa maior complexidade da divisão social e territorial do trabalho e das classes sociais.

Quanto maior o tamanho demográfico, maior a dimensão do espaço intra-urbano, expressa
pela distância entre o centro e a periferia da cidade, assim como mais complexa será a
organização desse espaço intra-urbano. Em razão das distâncias viabiliza-se em grande
parte, uma maior divisão econômica do espaço, submetido a um mais significativo processo
de descentralização, origem dispersa e formação de núcleos de atividades derivados de
economias de aglomeração, distantes do centro. Maior o tamanho demográfico e mais
complexas as atividades econômicas, suscitando maior fragmentação do tecido social, mais
complexa será a projeção espacial das classes sociais e suas frações, gerando uma mais
complexa divisão social do espaço, com áreas sociais mais diversificadas (CORRÊA, 2007,
p. 24).

A cidade média não é apenas uma cidade pequena que adquiriu um tamanho maior em função dos processos de industrialização e urbanização, ela apresenta uma reprodução socioeconômica diferente, com relações mais complexas do que a cidade pequena, das quais novos processos se destacam dessa complexidade, com arranjos territoriais e dinâmicas específicas.

Lefebvre (2016, p. 145), tratando da dialética entre os processos de industrialização e urbanização, afirma:

Nesse processo de duplo aspecto ocorre algo muito importante; em termos clássicos: um salto qualitativo. $\mathrm{O}$ crescimento quantitativo da produção econômica produziu um fenômeno qualitativo que se traduz, ele próprio, por uma problemática nova: a problemática urbana. 
Chama-se a atenção ainda para a necessidade de relativização dos conceitos de centro e de periferia, em virtude da maior complexidade das relações socioespaciais, uma abordagem dualística entre centro e periferia deixa de explicar as contradições dialéticas e continuidades entre esses dois espaços, além da formação de novas centralidades, seja na escala local, seja na constituição de uma rede urbana complexa.

Indaga-se ainda, o que há de novo na estruturação das cidades médias? Sposito (2007, p. 235-237) também discorre sobre a configuração de novas formas de articulação das cidades nas redes urbanas, que classifica de relações transversais, quando cidades de uma rede articulam-se com outras redes. Em trabalho sobre as cidades médias, a autora sustenta a necessidade de relacionar os estudos nas escalas intra-urbana e interurbana (região). Frente à complexificação das relações, propõe a relativização dos conceitos de centro e periferia, nas diversas escalas geográficas (intraurbana, regional, nacional e internacional).

\begin{abstract}
Verifica-se que as relações se sobrepõem em múltiplas escalas, não havendo a anulação ou superação completa de centros e periferias, mas tornando a geografias desses espaços menos geométrica e mais complexa, quando a comparamos às configurações que podíamos reconhecer antes [...] (SPOSITO, 2007, p. 241-242).
\end{abstract}

Em relação ao espaço intra-urbano, "a observação das novas formas de produção, propriedade e apropriação do espaço urbano, expressas pela constituição de uma cidade descontínua ou dispersa" (SPOSITO, 2007, p. 249). A autora aponta para o aumento das desigualdades e fragmentações socioespaciais:

Igualmente, nota-se a tendência para a fragmentação socioespacial, sem ainda atingir a tessitura política das relações, como se nota nas metrópoles, ainda que se tornem mais complexas as estruturas de distribuição das atividades econômicas e das funções sociais das cidades, com destaque para as residenciais, gerando enclaves de uso exclusivo em cidades médias (SPOSITO, 2007, p. 244).

Em outro estudo, a autora ressalta que a distância entre os desiguais na cidade não ocorre apenas ou principalmente pela lógica da periferização dos mais pobres e a ocupação das áreas centrais pelos mais ricos (SPOSITO, 2011), e propõe, apoiada em Massey, um conteúdo relacional do espaço, ou seja, a articulação das dimensões de tempo e espaço, em múltiplas escalas temporais e espaciais; resgatando nas formas espaciais esse conteúdo, particularmente as relações de poder aí existentes (SPOSITO, 2011).

Nesse propósito, consideramos ainda a práxis, a prática socioespacial, a partir da qual as estratégias de reprodução se materializam, em um determinado contexto histórico e geográfico. Pois, é esse conteúdo social produtor das formas que a teoria tenta captar e articular numa abordagem integrada (LEFEBVRE, 1979). 
Projetam-se assim, no contexto atual, não apenas transformações formais, mas uma verdadeira reestruturação, configurando uma cidade dispersa, fragmentada, em que os processos de segregação também assumem novos contornos, como na constituição de periferias complexas.

Considera-se ainda que a abordagem da morfologia urbana, só ganha sentido e conteúdo, quando se vai além das formas, quando "não se reduz a descrição dos objetos urbanos e de seu arranjo, mas inclui a repartição dos grupos sociais e dos papéis a serem desempenhados em cada espaço e por cada grupo" (SPOSITO, 2007, p. 248).

Com relação à rede urbana brasileira, Corrêa (2006, p. 318) destaca a sua reestruturação, especialmente a partir da década de 1980, como os diferentes modos de inserção do país no processo de globalização, concomitante ao avanço da integração do território nacional.

A refuncionalização que as cidades vêm passando, intensificada com a reestruturação produtiva a partir do processo de globalização econômica e financeira na década de 1980, vem acentuando as disparidades entre as cidades e configurando novas hierarquizações na rede urbana. A rearticulação da rede urbana com o incremento dos transportes e da circulação tanto aumenta a complementaridade entre as cidades, a exemplo da desconcentração da produção, como aumenta a competitividade entre elas, na busca de atração de investimentos, através de subsídios e isenções fiscais, desencadeando a chamada "guerra fiscal".

Corrêa (2006, p. 320-326) aponta que, diante de uma crescente especialização produtiva, divisão territorial do trabalho e complexidade funcional, a rede urbana passa a assumir padrões mais complexos com múltiplos circuitos, em que os centros urbanos não podem ser classificados apenas em suas funções centrais, mas também nas funções especializadas, passando a combinar interações em escala local e regional com aquelas de âmbito nacional e internacional. Um exemplo seria as mudanças na organização empresarial com as corporações multifuncionais e as múltiplas localizações em redes, como franquias e subcontratações; nos processos produtivos, modelos flexíveis, nos quais se verificam relocalização das unidades filiais, com dispersão das atividades e concentração do capital e das decisões.

A divisão social e territorial do trabalho também se aprofunda na escala intra-urbana; estrutura-se um espaço para atender a essas novas demandas, criando uma infraestrutura, especialmente ligada à circulação e comunicação, tendo como resultado um espaço urbano mais diferenciado, desigual e complexo.

De uma forma prática, Amorim Filho e Sena Filho (2007), em estudo sobre a morfologia das cidades médias mineiras, oferecem uma base comparativa a partir da caracterização morfológica e funcional das áreas centrais, pericentrais, periféricas e periurbanas. 


\section{RESULTADOS E DISCUSSÕES}

\subsection{A rede urbana no sul de Minas Gerais}

A rede urbana no Sul de Minas Gerais caracteriza-se por uma elevada densidade de pequenos centros originados no passado derivada de uma rede de localidades centrais, mínima divisão do trabalho, elevada densidade demográfica rural e pequena mobilidade da população (CORRÊA, 2006, p. 258-259). A instalação da rede ferroviária regional no final do século XIX ligando os centros urbanos do sul de Minas Gerais diretamente com os mercados de São Paulo e Rio de Janeiro restringiu a articulação entre esses centros regionais e a consolidação de uma cidade primaz. Atualmente, a região caracteriza-se por "uma rede urbana descentralizada, onde a função de centralidade é partilhada entre cidades médias, como Poços de Caldas, Varginha, Itajubá, Pouso Alegre, Passos e Lavras, e incluindo, por vezes, outras, como Alfenas, São Lourenço e Três Corações" (ANDRADE, 2014, p. 168).

A região Sul do Estado de Minas Gerais, especialmente a partir da duplicação da rodovia Fernão Dias, com início em 1995, passa a atrair empresas para os municípios próximos à divisa com o Estado de São Paulo, no quadro que se convencionou chamar de "guerra físcal". Cidades como Extrema e Pouso Alegre beneficiaram-se diretamente dessa desconcentração, apresentando altos índices de crescimento urbano.

Como referido anteriormente, as desigualdades na região também se acentuam, em virtude das diferentes potencialidades e vantagens que cada uma dessas cidades pode oferecer aos investimentos nacionais e transnacionais. No contexto de reestruturação produtiva, verifica-se uma reestruturação da rede urbana; de acordo com Corrêa (2006), há uma refuncionalização das cidades na rede urbana.

Em um processo de “desconcentração-concentrada", empresas, indústrias e mão-de-obra deslocam-se para algumas cidades médias que oferecem vantagens, além dos incentivos, não muito distantes das metrópoles da região Sudeste do país, como, por exemplo, no caso da metrópole paulista, as regiões do Vale do Paraíba e de Campinas (LENCIONI, 1991).

No âmbito do espaço intra-urbano, essas cidades também apresentaram significativas transformações (reestruturação): novas infraestruturas e equipamentos coletivos são instalados para abrigar empresas e população, tais como: rede viária, distritos industriais, hipermercados, shopping centers, condomínios fechados, conjuntos habitacionais, etc., indicando, em escala menor e em suas particularidades, modos de reprodução do espaço urbano de grandes cidades e/ou um movimento desses capitais em direção a esses novos mercados, como incorporadoras, construtoras, lojas de rede. 
No âmbito do espaço urbano, observa-se a intensificação da fragmentação, seja pelos processos de segregação socioespacial, seja pela expansão do tecido urbano, a exemplo dos condomínios fechados e distritos industriais.

Amorim Filho e Sena Filho (2007), apontam a formação de dois padrões periféricos: a periferia contínua (ou em mancha de óleo) e a periferia descontínua (ou polinuclear). Esta última, no que lhe concerne, apresenta duas unidades morfológicas: os bairros resultantes de loteamentos com populações bem integradas e as unidades mal organizadas.

\begin{abstract}
A expansão periférica em mancha contínua se dá tanto pelo crescimento do tecido urbano em suas bordas, quanto pela assimilação de núcleos formados por aglomerados [...] Os bairros resultantes de loteamentos que, embora possam apresentar grande diferenciação entre si, têm populações geralmente bem integradas aos sistemas econômicos, sociais, de transportes e comunicações [...] As unidades mal organizadas, denominadas localmente vilas e que, mesmo que se diferenciem fisionomicamente das favelas de cidades maiores, são habitadas por populações com grandes dificuldades para se integrarem aos sistemas ou circuitos formais que estruturam a vida de relações da cidade. Por isso, vários dos habitantes dessas vilas acabam por integrar-se aos circuitos informais urbanos ou, então, em certos casos, mesmo continuando a habitar esses núcleos periféricos, voltam a buscar trabalho na área rural, de onde vários deles haviam saído (AMORIM FILHO, 2007, p. 6970).
\end{abstract}

Os autores supracitados indicam, portanto, as dificuldades que a população das áreas periféricas tem para sua inserção no urbano, seja na dependência de atividades informais e/ou do campo para a sua sobrevivência. Por outro lado, pode-se apontar também uma maior ou menor dependência dessas cidades em relação ao espaço rural e as suas capacidades, em termos de funções urbanas, de absorverem parte da renda gerada no campo, o que repercute no alcance de suas polarizações.

\title{
3.2. Alfenas
}

Alfenas, assim como Poços de Caldas e região, situa-se entre as metrópoles da região Sudeste: Belo Horizonte, Rio de Janeiro, São Paulo e Campinas. Também está localizada em uma rede urbana no sul de Minas Gerais comandada por capitais regionais como Pouso Alegre, Poços de Caldas e Varginha (IBGE, 2020a). 


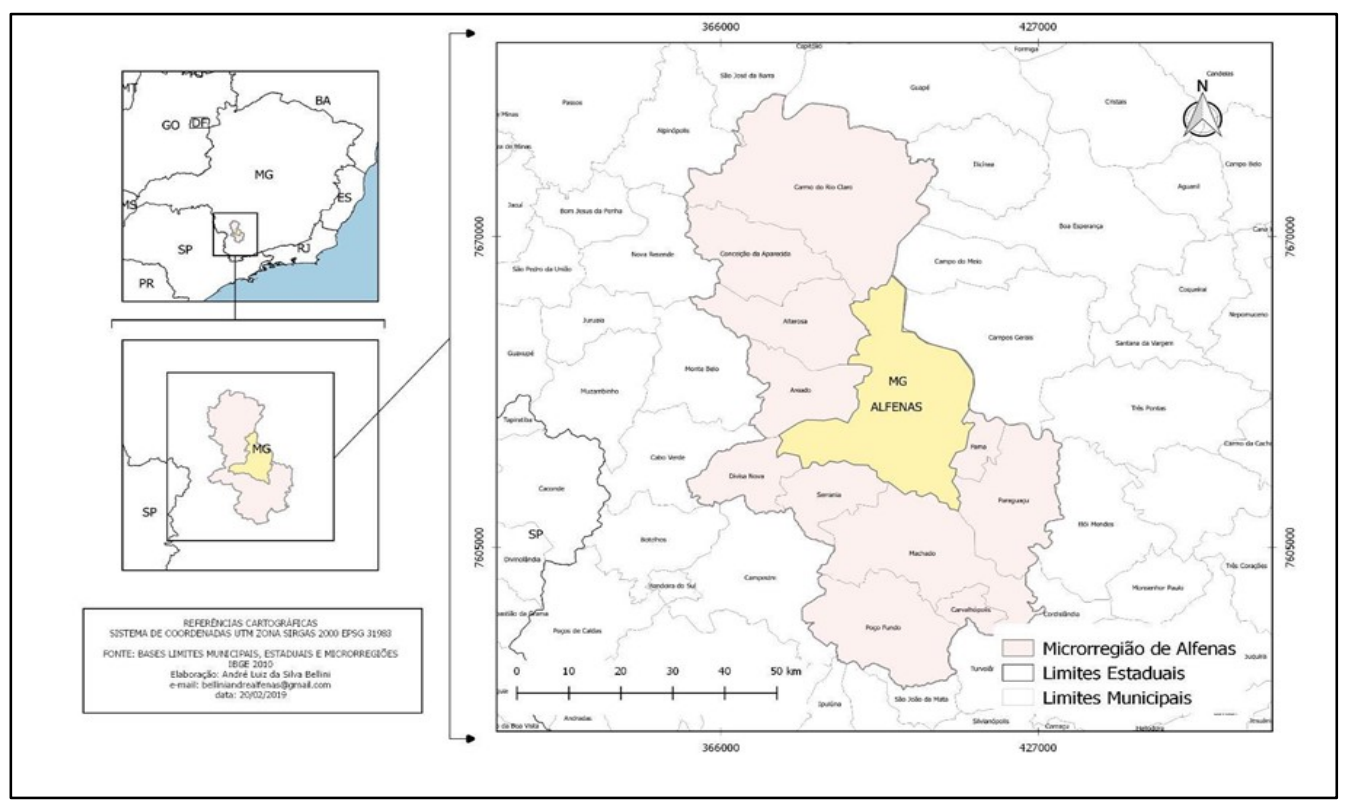

Figura 1 - Mapa de localização da sub-região de Alfenas MG.

Fonte: IBGE, 2010.

Elaboração: André Luiz da Silva Bellini, 2019.

Com uma população total estimada em 80,5 mil habitantes (IBGE, 2020b), observa-se no gráfico da figura 2 que a população urbana superou a rural em 1960, em função, entre outros fatores, da instalação do reservatório de Furnas para geração de energia elétrica, que deslocou populações ribeirinhas para as cidades da região, a exemplo de Alfenas. A partir desse período, o crescimento da população urbana é contínuo enquanto a população rural diminui em termos absolutos. Além dos processos de expulsão do campo, a cidade também atraiu, como na década de 1980, a instalação de cursos de ensino superior provoca uma crescente entrada de estudantes que chegam a compor dez por cento da população total do município, assim como parte dos migrantes sazonais ligados à colheita do café acaba fixando-se na cidade. É a partir desse período que o crescimento periférico se intensifica com a instalação de loteamentos com precária infraestrutura.

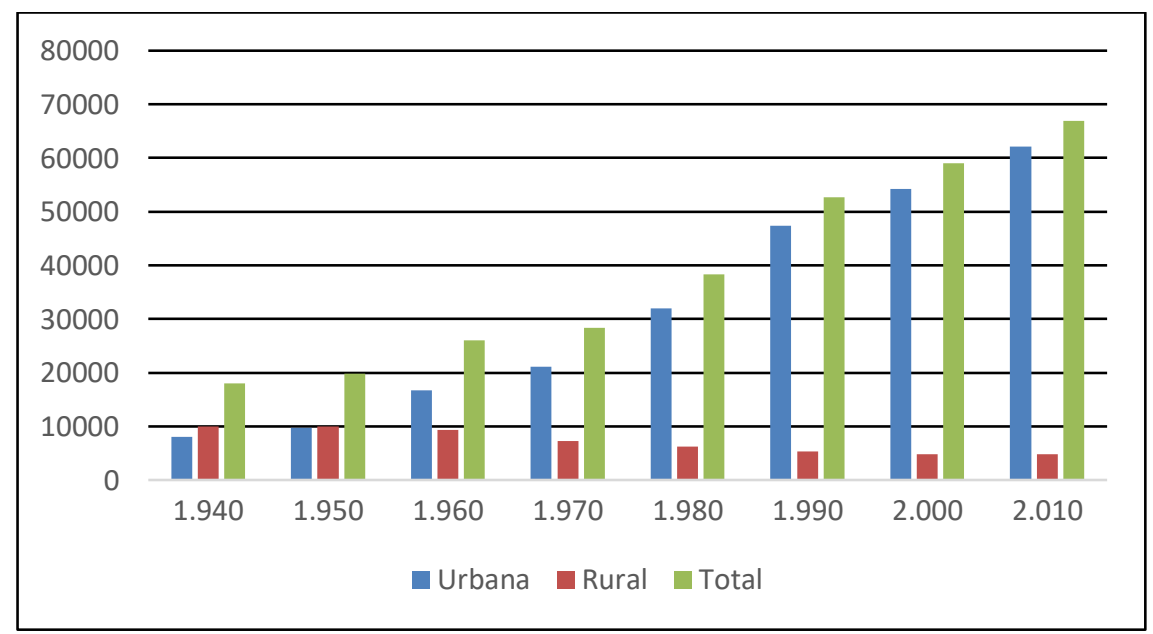

Figura 2 - Evolução da população urbana, rural e total do município de Alfenas de 1940 a 2010.

Fonte: IBGE, 2010. 
No período de dez anos, o Produto Interno Bruto (PIB) do município passou de 823 milhões de reais em 2007 para 2,6 bilhões em 2017, um crescimento de três vezes, com expressiva expansão do setor de serviços, o que corrobora o aumento da polarização regional, conforme se observa no gráfico da figura 3.

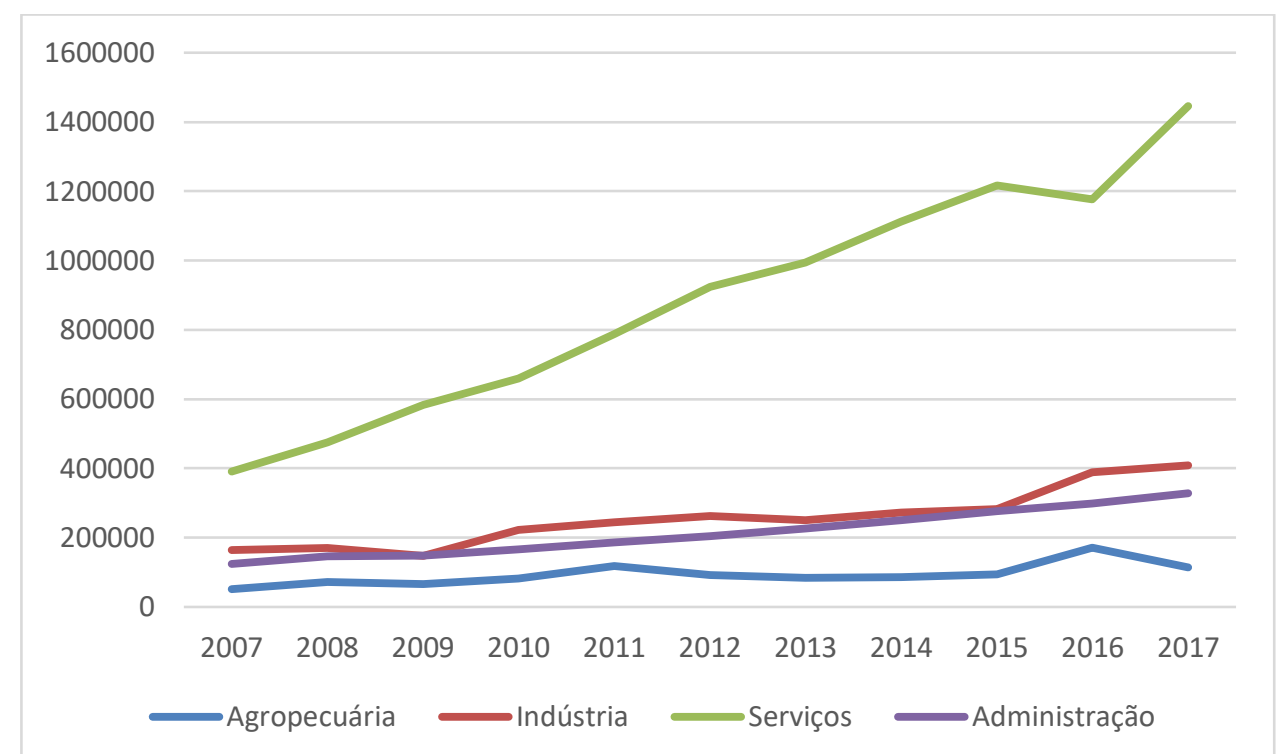

Figura 3 - Evolução do PIB por setores de atividade no município de Alfenas-MG entre 2007 e 2017 (x 1000) R\$. Fonte: IBGE, 2020c.

A instalação do reservatório de Furnas contribuiu para a desarticulação da rede de transporte ferroviário no sul de Minas Gerais, esta última sendo substituída pelo transporte rodoviário, que rearticulou a rede urbana. Esse novo arranjo modal beneficiou Alfenas que passou a articular uma rede de pequenas cidades em seu entorno ${ }^{1}$.

Alfenas, nesses últimos anos, vem apontando para uma nova escala de produção de seu espaço urbano e, portanto, de reprodução das relações sociais. Antes uma cidade de morfologia mais compacta e com um único centro urbano (monocêntrica), com tendência para uma expansão da mancha urbana difusa e segmentada, com a formação de novas áreas de consumo segmentado, indicando um padrão mais complexo e segregado (BRANQUINHO, 2021).

Chama a atenção a grande quantidade de novos empreendimentos em relação ao porte da cidade, em mais de uma dezena nesses últimos anos, revelando novas formas de exploração da renda do solo e de especulação imobiliária.

A expansão de novos loteamentos no entorno do Campus II da Unifal, a partir de sua implantação no bairro Santa Clara, é marcante, assim como a instalação de condomínios fechados

\footnotetext{
${ }^{1}$ De acordo com o Regiões de Influência das Cidades - REGIC de 2007 (IBGE, 2008), Alfenas aparece como um centro sub-regional polarizando os municípios de Alterosa, Areado, Campo do Meio, Campos Gerais, Conceição de Aparecida, Cordislândia, Divisa Nova, Fama, Guaxupé, Machado, Paraguaçu e Serrania.
} 
de alto padrão na região do bairro Aeroporto, que revelam as intensas desigualdades na reprodução desses espaços e novas formas de segregação-autossegregação.

Novos agentes produtores do espaço sobressaem, como as incorporadoras, com suas sofisticadas estratégias de reprodução de capitais ligadas ao setor imobiliário que acentuam exclusivos modos de consumo do espaço, como é no caso dos condomínios fechados. Por outro lado, a inércia geográfica de formas de reprodução pretéritas permanece, como a segregação da região dos bairros Vista Grande e Primavera. Na formação de uma periferia mais complexa, como no caso da região do Pinheirinho, houve a desconcentração de grandes equipamentos urbanos, como campus universitário, que promoveu novos usos do solo e o aparecimento de novas classes sociais.

A cidade destaca-se como polo de comércio e serviços para as cidades vizinhas, assim como é referência nos setores de saúde e de ensino superior, o que a consolidou como um centro sub-regional no sul de Minas Gerais (Figura 1).

Constata-se que a consolidação de Alfenas como cidade média tende a apresentar em sua atual fase de expansão setores mais definidos de segregação socioespacial, como, por exemplo, condomínios fechados na região do bairro Aeroporto, loteamentos de classe média na região do bairro Pinheirinho, e loteamentos e conjuntos habitacionais populares na região do bairro Primavera.

A cidade apresenta ainda um único centro, não desenvolvendo até o momento um subcentro importante, observa-se, portanto, na região do centro e seu entorno ainda a função residencial de parcela da população de maior poder aquisitivo, característica comum a uma cidade de porte pequeno, pois em cidades médias mais típicas predominam a função comercial e outros serviços com maior grau de especialização. Mas o atual crescimento da cidade e a recente expansão dos condomínios fechados indicam a formação de um eixo de expansão e de um setor de valorização na parte leste da cidade, na região do bairro Aeroporto, onde já havia a ocupação com moradias de alto padrão.

Trata-se de transformações importantes, que indicam uma reestruturação, um novo patamar que a cidade alcança, a mudança de função do centro para eminentemente terciário, com o deslocamento da população de classe alta para um setor específico de valorização, com consequências para a cidade como um todo, é acompanhado de desconcentração de atividades do centro que seguem esses estratos, ao mesmo tempo que estabelece setores valorizados, com a formação de novas centralidades, define a expulsão de população mais pobre para os outros setores menos valorizados, ou seja, impõe a segregação às outras classes com menor opção de escolha, junto à expansão da mancha urbana (Figura 4). 


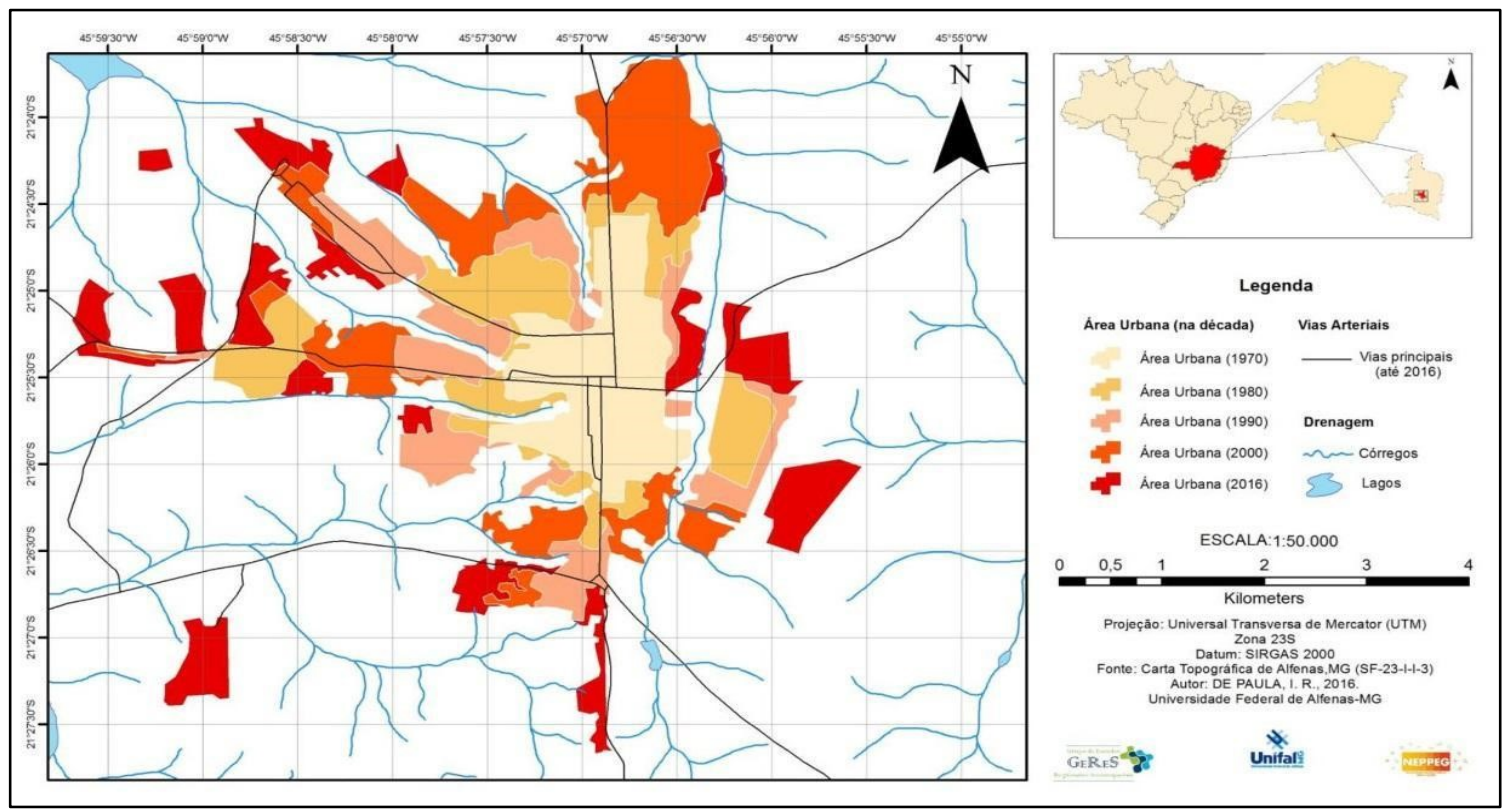

Figura 4 - Mapa da Expansão Urbana de Alfenas-MG.

Elaboração: Igor de Paula, 2016.

Como resultado desse processo, constitui-se uma cidade apropriada desigualmente, conforme os interesses e poderes de cada classe ou estrato social, sendo assim, uma cidade onde se evidencia a segregação socioespacial. É importante destacar o papel do Estado como instituição que carrega as contradições da sociedade, e assegura a reprodução das relações sociais colocadas, como principal agente produtor do espaço, qualificando e valorizando desigualmente este de acordo com as suas estratégias de intervenção.

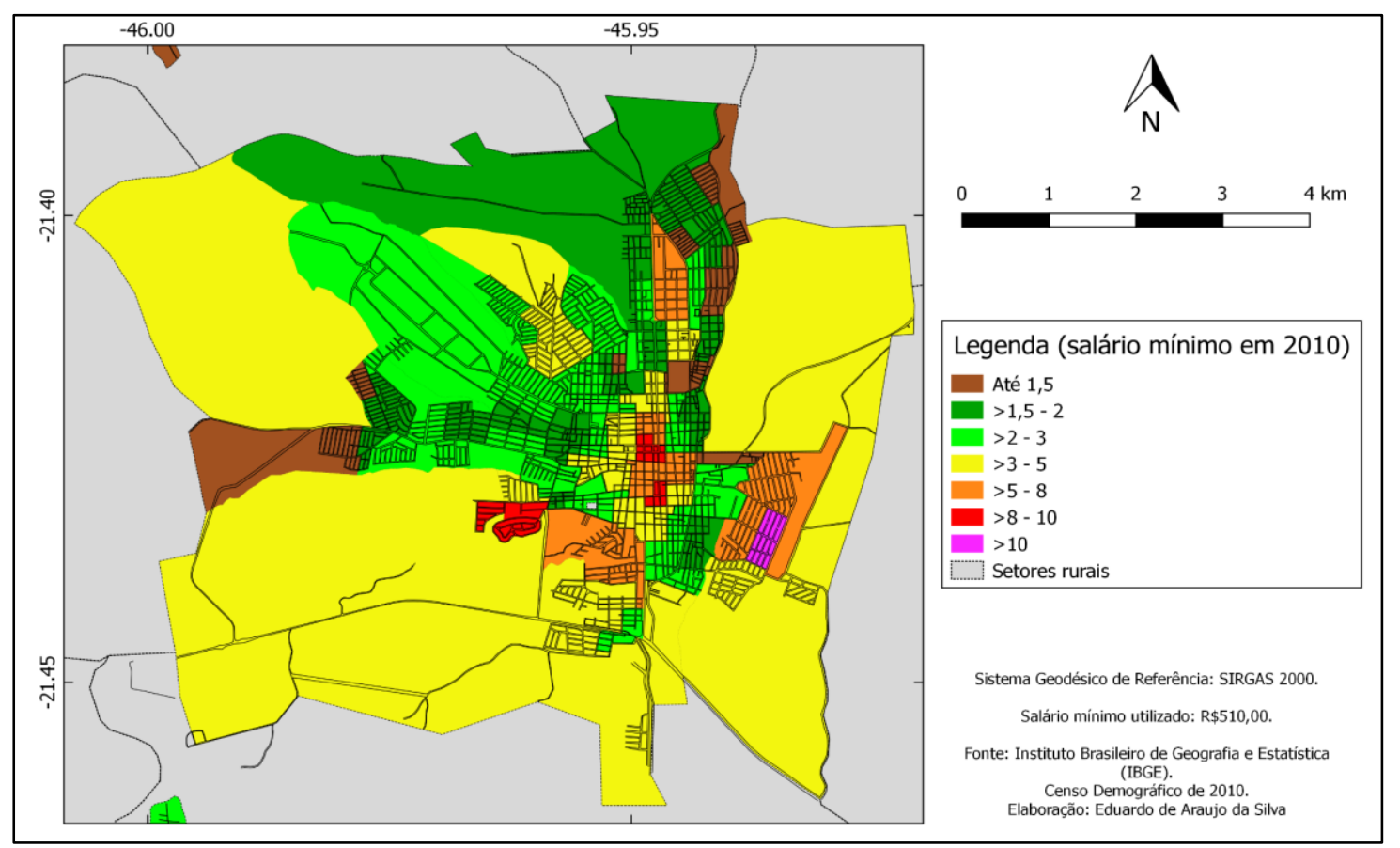

Figura 5 - Valor do rendimento nominal médio mensal das pessoas responsáveis por domicílios particulares permanentes com rendimento de Alfenas-MG (setores urbanos)

Organização e elaboração: autores. 
Chama a atenção em bairros periféricos como o Pinheirinho e o Santa Clara, constatado em questionários e entrevistas, uma parcela da população que se dedica ao trabalho sazonal de colheita do café (BRANQUINHO, 2021), o que indica, como apontou Amorim Filho (2007), as dificuldades de inserção dessa população à cidade e ao urbano.

\subsection{Poços de Caldas}

Por sua vez, Poços de Caldas, localizada junto à divisa estadual de Minas Gerais e São Paulo, apresenta o maior contingente populacional do Sul de Minas. Estima-se que sua população seja de 168,6 mil habitantes, sendo esta majoritariamente urbana (aproximadamente 97\%) (IBGE, 2010; IBGE, 2020b). Assim como Varginha e Pouso Alegre, a cidade é classificada como uma capital regional na mesorregião Sul/Sudoeste de Minas Gerais (IBGE, 2020a).

Além do tamanho demográfico, Poços de Caldas também se destaca na região devido a sua diversidade econômica. No município, encontra-se uma variedade de atividades econômicas dos setores primário, secundário e terciário. Na economia local, as atividades do setor primário se apresentam menos relevantes no PIB do município (cerca de $0,6 \%$ ), enquanto as atividades do setor terciário são as que geram maior impacto (acima de 61\%). Observa-se, na tabela 1, que, se comparado ao PIB de Alfenas, o PIB de Poços de Caldas corresponde a cerca de $242 \%$.

Tabela 1: Composição setorial do PIB de Poços de Caldas, 2000, 2010 e 2017 (valor em R $\$ 1.000,00)$.

\begin{tabular}{c|c|c|c|c|c}
\hline Ano & Agropecuária & Indústria & Serviços & Impostos & Total \\
\hline 2000 & 23.440 & 638.919 & 693.379 & 292.415 & 1.648 .153 \\
2010 & 34.312 & 1.009 .142 & 2.145 .593 & 553.033 & 4.617 .828 \\
2017 & 39.466 & 1.441 .983 & 3.893 .705 & 990.785 & 6.365 .940 \\
\hline
\end{tabular}

Fonte: IBGE, 2020c. Dados organizados por Silva, 2021.

Seu setor primário é composto por 31 empresas, com atividades de agricultura, pecuária, produção florestal, pesca e aquicultura (IBGE, 2018). As atividades primárias na economia local se mostram menos relevantes desde os anos 1970, período em que se iniciou uma considerável reestruturação da cidade a partir do duplo processo de industrialização-urbanização. Na produção primária local há a produção de leite, café, batata e de suínos. No que diz respeito ao café, este é produzido no município desde a última década do século XIX (MEGALE, 1990; SEGUSO, 2007).

Por seu turno, o setor secundário local é mais desenvolvido, composto por 902 indústrias de diversos portes e ramos econômicos. Há 85 indústrias extrativistas (extração de minerais metálicos, minerais não-metálicos e atividades de apoio à extração); 444 indústrias de 
transformação (produção de alimentos, bebidas, produtos têxteis, vestuários, marcenaria, produtos químicos, produtos plásticos, produtos metálicos, automóveis, dentre outros); e 373 empresas de construção (construção de edifícios, obras de infraestruturas e serviços especializados de construção) (IBGE, 2018). As indústrias de médio e grande porte, sobretudo as de mineração e transformação de minérios, promovem articulações de Poços de Caldas com outras redes urbanas (nacionais e internacionais), as denominadas relações transversais (SPOSITO, 2007).

O setor terciário da cidade é amplamente diverso, há atividades atreladas ao turismo de cura e lazer, administração pública, instituições de ensino de todos os níveis, atividades comerciais e de serviço especializados, dentre outros. Ao todo, há mais de 5 mil empresas cadastradas que compõem o setor terciário local (IBGE, 2018). Dentre as atividades desse setor, destaca-se a oferta de serviços médicos especializados, fazendo que a cidade se torne um polo regional de serviços médico-hospitalares (OLIVEIRA, 2012).

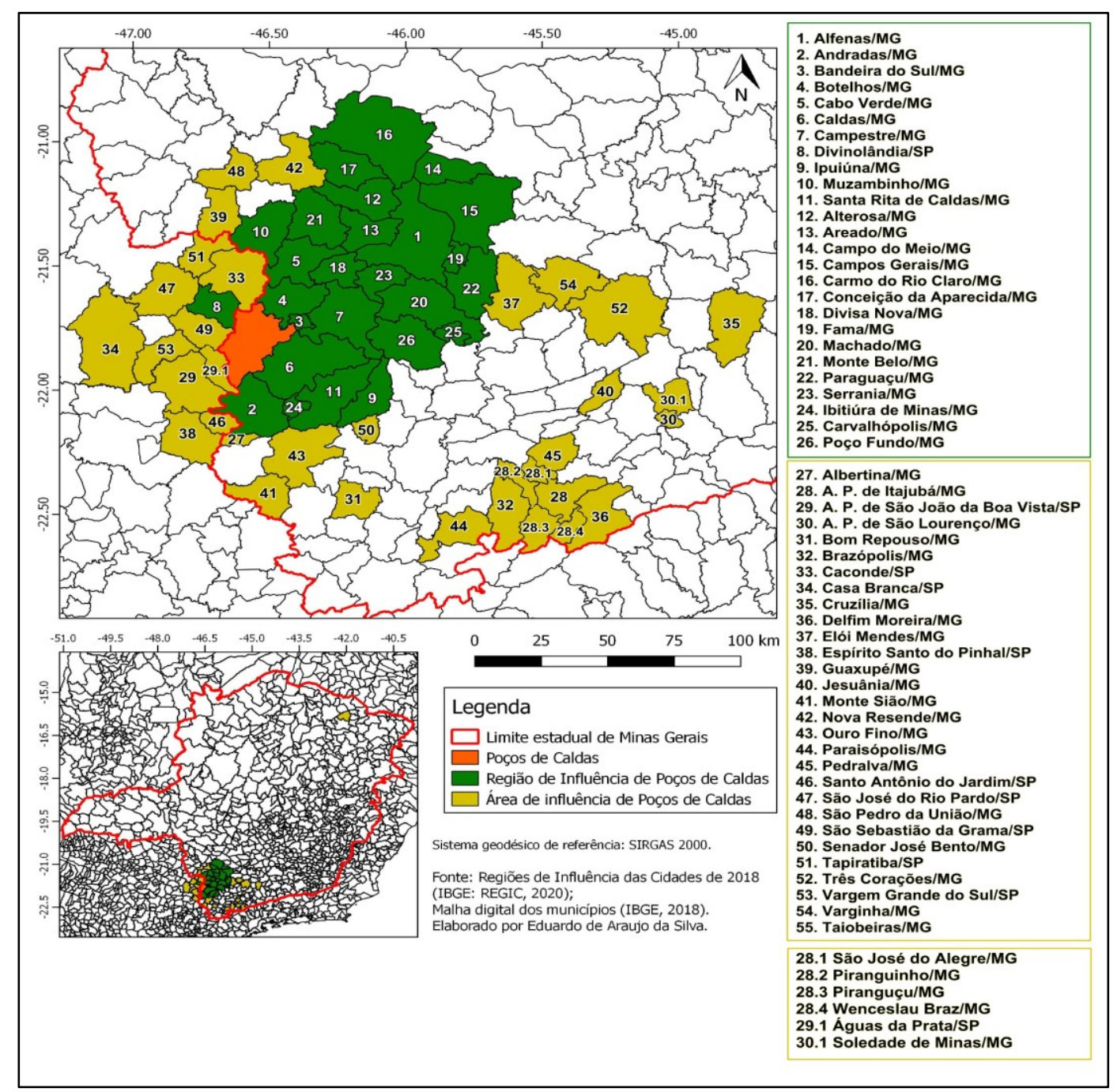

Figura 6 - Mapa da região e área de influência de Poços de Caldas-MG.

Fonte: Silva, 2021. 
A elevada oferta de comércio e serviços em seu território faz que Poços de Caldas polarize uma quantidade considerável de núcleos urbanos de médio e pequeno porte, sobretudo aqueles localizados no sul do Estado de Minas Gerais (Figura 6). De acordo com os dados do último REGIC (IBGE, 2020a), a cidade polariza diretamente 26 outros núcleos urbanos, e sua região e área de influência, juntas, abrangem um total de 61 municípios mineiros e paulistas. Conforme já mencionado, Poços de Caldas polariza Alfenas em sua região de influência.

Relativo ao crescimento populacional, econômico e urbano, esses podem ser explicados pela história local. A formação e a consolidação de Poços de Caldas (como uma cidade de destaque na região) se processou, inicialmente, em torno dos recursos naturais disponíveis em seu sítio urbano (SILVA, 2021).

$\mathrm{Na}$ localidade há o recurso natural das águas sulfurosas, descobertas por volta do século XVIII. No século XIX, o Governo mineiro e junto às classes dominantes locais e da região somaram seus esforços para fundar um núcleo urbano junto aos poços de águas sulfurosas, seus interesses estavam alinhados, e o intuito desse grupo era construir um balneário de reconhecimento internacional na localidade. Portanto, Poços de Caldas foi uma cidade minuciosamente planejada (MARRAS, 2004).

Para que a cidade se desenvolvesse conforme o desejado pelas elites, era necessário que a produção do seu espaço fosse voltada à exploração das águas, dessa forma, foram levantados balneários e espaços de lazer para os visitantes, como redes hoteleiras e diversos cassinos. Além disso, o sistema de transportes até a localidade foi melhorado: foram abertas novas estradas até Poços de Caldas, e houve a implantação de um ramal ferroviário, que fortaleceu a inter-relação da cidade com outras cidades no entroncamento das linhas ferroviárias da região Sudeste, e importantes capitais, como São Paulo e Rio de Janeiro (SILVA, 2021).

Portanto, o espaço urbano local se desenvolveu crescentemente desde sua fundação, em 1872. Desse modo, a cidade ganhou notoriedade na região, de modo que, logo nos primeiros estudos sobre aspectos das regiões urbanas do Brasil (GEIGER; DAVIDOVICH, 1961), ela já se mostrava como um centro urbano de destaque no Sul de Minas.

Conforme os estudos de Geiger e Davidovich (1961), na década de 1950, Poços de Caldas estava inserida na região urbana de São Paulo, sendo a cidade mais importante de todo o Sul de Minas. Nesse período, Poços de Caldas foi classificada como um centro de $1^{\text {a }}$ Categoria, essa categoria era dada para as cidades que possuíam de 10 a 30 mil habitantes, que estavam em entroncamentos ferroviários e/ou que possuíam algum desenvolvimento industrial. Outras cidades que apresentavam certo destaque na região eram Itajubá e Varginha, ambas classificadas como centro de $2^{\text {a }}$ Categoria. Por sua vez, esta última classificação correspondia aos centros urbanos em 
zonas agrícolas, submetidas às flutuações de ritmo de crescimento, sendo cidades antigas que ainda não tinham sido contempladas pelos processos de industrialização.

Logo nos anos 1960, Poços de Caldas passou por um crescente processo de industrialização, acarretado pelo desenvolvimento dos setores de mineração, que estavam em processo nas décadas anteriores (OLIVEIRA, 2012). Tanto a mineração quanto a industrialização se beneficiaram das infraestruturas de circulação dispostas na cidade. Em Poços de Caldas, havia um ramal ferroviário da Cia. Mogiana Estradas de Ferro, que tinha sido inaugurada desde a década de 1880. Essa ferrovia, que estava entroncada com outras ferrovias importantes da região Sudeste, serviu para escoar produtos agrícolas, produtos da extração mineral e, posteriormente, para o escoamento dos produtos industrializados. Também, o trecho era utilizado para o fluxo de pessoas, contribuindo para o desenvolvimento do turismo local, desde as primeiras décadas da existência do núcleo urbano. $\mathrm{Na}$ atualidade, o ramal só é utilizado para escoar produtos das atividades de mineração.

Os setores de mineração e industrialização (transformação de minerais) indicam uma especialização da cidade na divisão técnica e territorial do trabalho, no que, atualmente, são ofertados cursos e especializações nessas áreas econômicas: Bacharelado em Engenharia de Minas e Mestrado em Engenharia de Materiais, com linhas de pesquisa sobre ligas metálicas, compostos cerâmicos e biomateriais (PPGCEM UNIFAL-MG, 2019).

Em função do processo de industrialização, a cidade passou por significativas mudanças, havendo expressivo crescimento populacional e do território urbano nas décadas seguintes. Concordando com Lefebvre (2008), os processos de industrialização e urbanização devem ser contemplados como um único processo conflitante, ou seja, um “duplo processo". Este autor considera que, quando as indústrias se fixam, a cidade passa por diversas transformações. A partir da industrialização, são criados centros financeiros, técnicos, de gestão, subúrbios, bairros operários, favelas, dentre outros, assim, contribuindo para o crescimento da aglomeração. Nessa conjuntura, o processo de segregação se intensifica.

Observa-se, na figura 7, que a partir dos anos 1970, após o “duplo processo", o território urbano de Poços de Caldas se expandiu expressivamente, no que sua morfologia urbana tornou-se Poços de Caldas crescentemente dispersa e fragmentada (SILVA, 2021). 


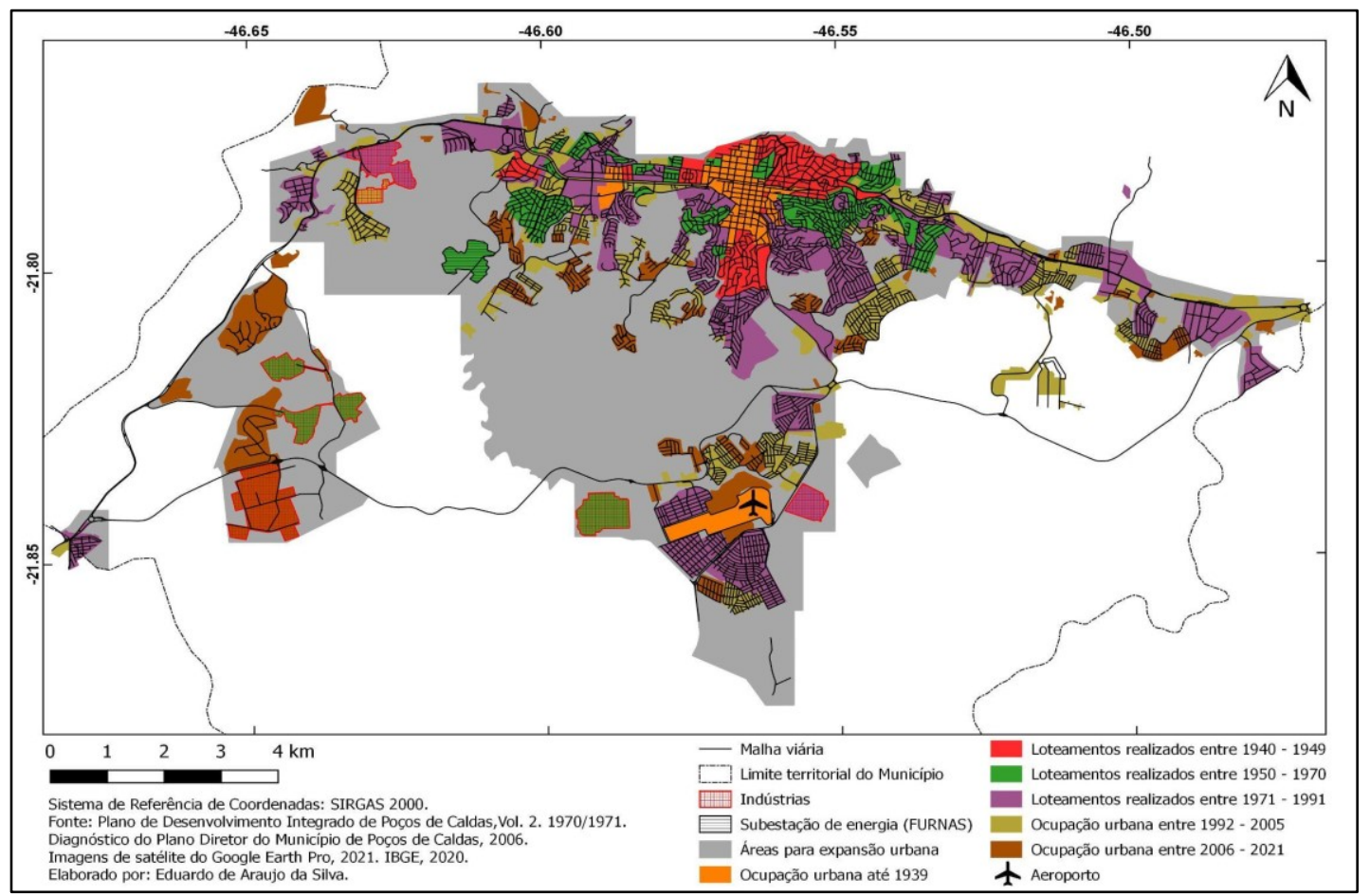

Figura 7 - Mapa do crescimento do espaço urbano de Poços de Caldas

Fonte: Silva, 2021.

Andrade (2005) afirma que as zonas Leste e Sul foram os setores urbanos que receberam parte do expressivo crescimento populacional a partir dos anos 1970. Conforme o autor, a expansão da população urbana "recente" ocorreu nos eixos leste e sul.

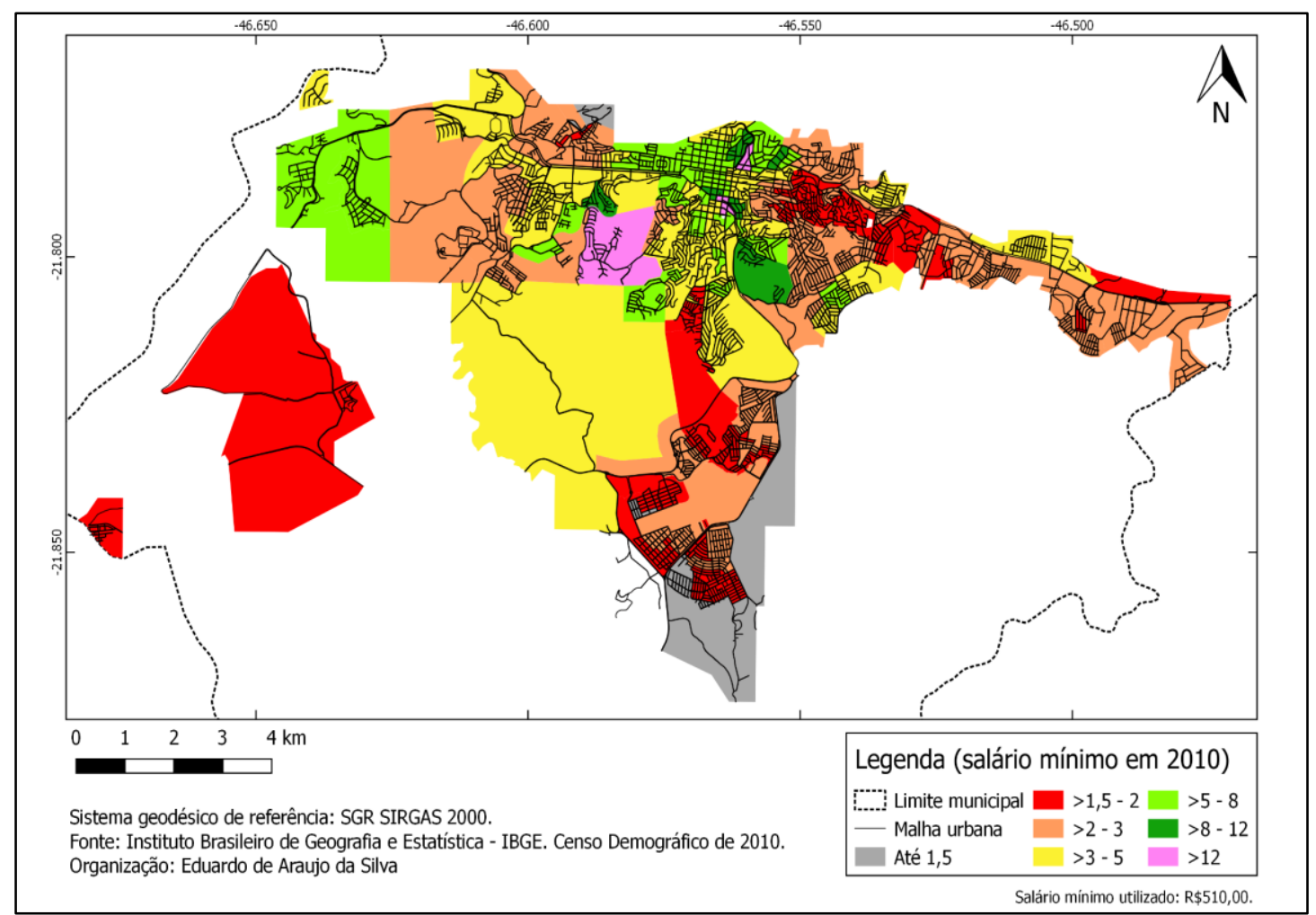

Figura 8 - Valor do rendimento nominal médio mensal das pessoas responsáveis por domicílios particulares permanentes com rendimento de Poços de Caldas-MG (setores urbanos)

Fonte: Silva, 2021. 
Até nos dias atuais, de um modo geral, os rendimentos mensais médios das populações residentes nas zonas Sul e Leste se apresentam menores, se comparados aos rendimentos das populações residentes em outros setores urbanos (Figura 8). Em contrapartida, os bairros ocupados pelos segmentos sociais de maior poder aquisitivo estão localizados no centro principal, zona pericentral e em alguns bairros localizados na Zona Oeste.

De acordo com Silva (2021), há processos de segregação socioespacial na cidade, nos três eixos de expansão (Leste, Oeste e Sul). Conforme o autor, boa parte da população da Zona Sul se encontra segregada em função de baixos rendimentos; as áreas mais periféricas e descontínuas na Zona Leste também expõem a segregação socioespacial local (como processo, forma e condição segregada de seus residentes). Por seu turno, a Zona Oeste é composta por segmentos sociais de poderes aquisitivos variados. Nela se encontram tanto bairros com baixos níveis de infraestrutura e índices socioeconômicos inferiores (Chácara Santa Bárbara, por exemplo) e os denominados espaços residenciais fechados (SPOSITO; GÓES, 2013), em áreas distantes e descontínuas do território urbano geral.

\section{ANÁLISE COMPARATIVA ENTRE AS DUAS CIDADES}

Considerou-se como base principal para a comparação entre as cidades de Alfenas e Poços de Caldas o estudo "Morfologia das cidades médias" (AMORIM FILHO; SENA FILHO, 2007), cuja proposição é comparar o zoneamento morfológico-funcional intra-urbano das cidades médias mineiras, a partir da análise das zonas centrais, pericentrais, periféricas e periurbanas dessas cidades. Amorim Filho (2007) sustenta que, apesar das diferenças no processo histórico e de aspectos físicos dessas cidades, “[...] há uma tendência, observada nas cidades médias, para um padrão morfológico-funcional parecido [...]” (p. 71), ao menos comparativamente às cidades pequenas e às cidades grandes e metrópoles, para as quais se constatam características particulares.

No que diz respeito ao zoneamento morfológico-funcional, Amorim Filho (2007) apresenta um quadro sistematizado para cada nível da hierarquia urbana (cidade pequena, cidade média, grande cidade, região metropolitana ou metrópole e megalópole). A tabela 2 expõe o zoneamento morfológico-funcional no nível hierárquico da cidade média: 
Tabela 2: Zoneamento morfológico-funcional e níveis de hierarquia urbana: cidades médias.

\begin{tabular}{|c|c|c|c|}
\hline Zona Central & Zona pericentral & Zona periférica & Zona periurbana \\
\hline $\begin{array}{l}\text { Centro principal bem } \\
\text { definido funcionalmente } \\
\text { (forte presença de } \\
\text { equipamentos "raros", de } \\
\text { alcance regional); } \\
\text { diferenciação funcional } \\
\text { interna; paisagem e } \\
\text { morfologia típicas } \\
\text { (construções em altura; } \\
\text { maior densidade de } \\
\text { construções; forte } \\
\text { movimento de veículos e } \\
\text { de pessoas, animação); } \\
\text { função residencial } \\
\text { superada pelas funções } \\
\text { terciárias; centro com } \\
\text { polarização pelo menos } \\
\text { microrregional, podendo } \\
\text { alcançar o nível regional } \\
\text { de polarização. }\end{array}$ & $\begin{array}{l}\text { Extensa espacialmente; } \\
\text { função residencial } \\
\text { predominante; presença } \\
\text { de subcentros } \\
\text { especializados ou } \\
\text { polifuncionais, ao longo } \\
\text { dos eixos, de praças e de } \\
\text { entroncamentos; } \\
\text { diferenciação } \\
\text { morfológica e } \\
\text { paisagística em função } \\
\text { de diferenças sócio- } \\
\text { econômicas; presença de } \\
\text { equipamentos especiais } \\
\text { como hospitais, } \\
\text { universidades, casernas, } \\
\text { estações rodoviárias e } \\
\text { ferroviárias, etc. }\end{array}$ & $\begin{array}{l}\text { De dois tipos: contínua } \\
\text { (como prolongamento da } \\
\text { zona pericentral) e } \\
\text { descontínua, ou } \\
\text { polinuclear, formada por } \\
\text { loteamentos (unidades } \\
\text { organizadas) ou "vilas" } \\
\text { (desorganizadas e, em } \\
\text { certas regiões, } \\
\text { verdadeiras favelas); } \\
\text { presença de subcentros } \\
\text { polifuncionais bem } \\
\text { modestos (comércio e } \\
\text { serviços de vizinhança) e } \\
\text { de alguns subcentros } \\
\text { especializados; extensão } \\
\text { proporcional ao nível } \\
\text { hierárquico e tamanho da } \\
\text { cidade. }\end{array}$ & $\begin{array}{l}\text { Presença de uma zona } \\
\text { de transição urbano } \\
\text { rural mais ou menos } \\
\text { extensa, e que se } \\
\text { confunde, nas } \\
\text { imediações da cidade, } \\
\text { com a periferia } \\
\text { polinuclear e } \\
\text { descontínua; presença } \\
\text { de alguns } \\
\text { equipamentos } \\
\text { terciários pontuais; } \\
\text { aumento das casas de } \\
\text { campo, de clubes } \\
\text { campestres e hotéis- } \\
\text { fazenda; diminuição } \\
\text { das fazendas e } \\
\text { aumento das pequenas } \\
\text { propriedades com } \\
\text { produtos para a cidade } \\
\text { média. }\end{array}$ \\
\hline
\end{tabular}

Fonte: Amorim Filho, 2007, p. 72. Adaptado.

Nas seções a seguir, apresentamos a caracterização dessas zonas morfo-funcionais para as cidades de Poços de Caldas e Alfenas, estabelecendo uma comparação, de modo aproximativo, de seus espaços intra-urbanos.

\subsection{Zona Central}

Conforme mencionado anteriormente, a zona central de Alfenas ainda apresenta-se como a única centralidade da cidade, ocupando uma área de cinco a seis quadras em torno das duas praças principais que conformam o centro, que além dos principais equipamentos de comércio e serviços, abriga ainda a função residencial de camadas de alto poder aquisitivo, com pouca verticalização, e apenas mais recentemente sua expansão para áreas do entorno, seu pericentro, acompanhada de algumas atividades que servem estas camadas, e para a periferia com desconcentração de alguns equipamentos urbanos como a rodoviária, supermercados, universidade e condomínios fechados.

Por sua vez, Poços de Caldas possui uma zona central maior, composta por uma rede de serviços e comércio consideravelmente ampla e especializada; pela maioria das sedes de instituições de interesse coletivo (Prefeitura, escolas, igrejas, fórum, hospitais, dentre outras); edificações tombadas como patrimônios histórico-culturais e pontos turísticos (espaços que favorecem no paisagismo local); além disso, a zona central de Poços de Caldas é local de residências, e por causa desses fatores, atualmente, o centro principal se apresenta altamente verticalizado. Dessa maneira, o 
centro principal local atende às demandas tanto da população residente quanto de um espaço regional mais amplo, que abrange cidades do Sul de Minas e do interior paulista. Ressalta-se que, diferentemente de Alfenas, Poços de Caldas possui outras áreas que exercem centralidade (subcentros), no entanto, o centro principal ainda é o mais importante, assegurando a própria unidade da estrutura urbana local.

\subsection{Zona pericentral}

A área pericentral de Alfenas compreende uma área de cinco quadras em torno do centro, predomina a função residencial de camadas médias da população, onde mais recentemente, verificase a desconcentração de camadas altas do centro, com a demolição de imóveis mais antigos para a construção de residências de alto padrão, prédios de apartamentos, e consultórios, com destaque para os principais eixos de interligação para as áreas periféricas, que constituem zonas de comércio, como na zona sul, nas redondezas da Unifenas e hospital, onde se desenvolve atividades ligadas aos estudantes, com um comércio variado, oficinas e peças de veículos, atividades não nobres expulsas da área central; algumas áreas periféricas em função da acessibilidade transforma-se em pericentro, como os eixos que cortam os bairros de Vila Betânia e Boa Esperança.

Em Poços de Caldas, a zona pericentral estende-se consideravelmente nas direções leste, sul e oeste (áreas de fundo de vale), e em menores proporções nas direções: sudoeste, sudeste e nordeste (áreas com maiores declividades). Nas direções noroeste e norte não há expansão urbana devido ao atributo fisiográfico da Serra de São Domingos. No que diz respeito à Serra, esta não foi ocupada devido à alta declividade do terreno e aos mecanismos de proteção das matas locais. As zonas pericentrais ocupadas têm função predominantemente residencial, com diversidade de classes sociais e atividades do setor terciário.

Nos eixos principais de expansão leste (Rua Dr. Mário de Paiva, Rua Cel. Virgílio Silva e Av. José Remígio Prezia), oeste (Av. João Pinheiro e Av. Champagnat) e sul (Av. Santo Antônio), há maiores usos do solo para fins comerciais ou de prestação de serviços. Contudo, observa-se intensa verticalização nas áreas pericentrais, onde estão sendo levantados prédios residenciais. Ressalta-se ainda que os valores dos terrenos dessas áreas são expressivamente altos.

\subsection{Zona periférica}

A área periférica de Alfenas concentra-se mais nas porções norte e oeste da mancha urbana, onde, desde a década de 1960, foi implantada uma série de loteamentos e conjuntos habitacionais voltados às camadas de menor rendimento, a exemplo dos bairros Pinheirinho e Vista Grande. Mais recentemente, com a desconcentração de grandes equipamentos urbanos, como 
distrito industrial, campus universitário e condomínios fechados, algumas áreas periféricas, houve a atração de novos loteamentos destinados aos segmentos médios da população, formando periferias mais complexas e de segregação intensiva. Apresenta ainda uma periferia mais contínua, o que caracteriza uma mancha mais compacta, todavia a grande expansão de novos loteamentos apresenta tendência à fragmentação e dispersão da mancha urbana, por meio tanto de condomínios horizontais fechados quanto a novos loteamentos populares mais afastados e desarticulados da mancha urbana, a exemplo de Poços de Caldas apresenta uma periferia mais extensiva, sobretudo nas zonas leste e sul, com maior dispersão e fragmentação da mancha urbana.

Observa-se que Alfenas, devido ao seu estágio de desenvolvimento do espaço intra-urbano, sua zona periférica não se estende mais do que quatro quilômetros (nas direções norte e oeste, sendo estas as mais prolongadas). Suas periferias são contínuas à zona pericentral, aliás, pouco se diferencia a zona pericentral de uso residencial das periferias ocupadas para o mesmo uso. No entanto, apesar de contínuas, as periferias ocupadas pela população de baixo poder aquisitivo mostram-se menos integradas (social e economicamente), denotando o processo de segregação socioespacial. Em contrapartida, na zona periférica sudeste (mais integrada socioeconomicamente e mais contínua espacialmente) há expansão urbana para uso residencial das camadas sociais de maior poder aquisitivo, com processo de condominização (Jardim Aeroporto).

No que tange à zona periférica de Poços de Caldas, esta é expressivamente extensa e diversificada, se comparada a Alfenas (ver e comparar Figura 5 e Figura 8). Observa-se que nos três eixos principais de expansão (leste, oeste e sul) as periferias são descontínuas e estão cerca de dez quilômetros do centro principal. Em função da distância, houve a formação de novas centralidades nesses setores urbanos. No eixo de expansão urbana sudoeste, houve primeiramente a concentração de indústrias de médio e/ou grande porte, por volta dos anos 1970. Após os anos 2000, foi criado um distrito industrial no setor sudoeste e, em seguida, foram implantados espaços residenciais fechados de médio e alto padrão nessa localidade.

Devido às maiores distâncias das periferias com o centro principal, observa-se uma maior especulação imobiliária em vazios urbanos dotados de infraestrutura, se comparada à situação de Alfenas. Também, a segregação socioespacial (de Poços de Caldas) da população periférica de baixo poder aquisitivo se revela mais intensa, onde boa parte dessa população não consegue acesso aos comércios, serviços e empregos formais do centro.

Em contrapartida à segregação socioespacial das populações de baixo poder aquisitivo, a autossegregação da população de médio e alto poderes aquisitivos também revela-se intensa, no setor urbano oeste da cidade. Esse processo iniciou-se a partir dos anos 2000, e junto a autossegregação, houve a formação de novas centralidades (eixos com concentração de comércios e serviços e um shopping center) para atender essas populações (SILVA, 2021). 


\subsection{Zona periurbana}

A zona periurbana de Alfenas não é muito extensa, confundindo-se na transição da área periférica e rural, onde muitas vezes essa passagem se dá de modo abrupto, como no Pinheirinho, Santa Clara e Oliveiras, onde ocorrem sítios, chácaras e pastagens. Esses espaços estão entremeados com áreas de plantio de café e com instalações de novos loteamentos, a exemplo do entorno do campus II da Unifal e, mais recentemente, da construção da avenida Perimetral Oeste, que atravessa uma área rural; também há instalação de condomínios nas proximidades da represa de Furnas.

Em Poços de Caldas a zona pericentral estende-se por alguns quilômetros, sendo formada por um anel de sítios, fazendas, motéis, hotéis, clubes, casas de campo, e outros equipamentos terciários pontuais. Devido à alta dispersão e fragmentação da periferia urbana local, é dificultoso diferenciar as áreas descontínuas (polinuclear) da zona periférica das áreas de uso misto da zona periurbana.

Desde o início do século XXI, há formações de territórios urbanos descontínuos em meio a zona periurbana. Foram levantados espaços residenciais fechados compostos de sistemas de vigilância particular. Esses empreendimentos são destinados aos segmentos sociais de médio e alto poder aquisitivo.

\subsection{Outros aspectos da comparação}

A relação rural-urbana das duas cidades, nível de articulação e dependência do setor agrícola, é distinta, assim como a capacidade de drenagem e consumo da renda do campo. Em Alfenas há vários serviços voltados a esta atividade, como: comércio de máquinas agrícolas, insumos, distrito industrial com várias empresas agrícolas, armazenagem, etc., que dependem mais dos recursos gerados no campo assim como da oferta de trabalho. Em Poços de Caldas, conforme mencionado, há uma economia mais diversificada e especializada, sendo mais industrializada proporcionalmente. Seu alcance sobre o campo é maior, com menos dependência deste, e maior capacidade de captar a renda fundiária.

A renda da terra urbana é um forte componente da extração da mais-valia urbana. Ela pode indicar uma mudança de escala dos agentes produtores do espaço, os quais se destacavam famílias tradicionais que se dedicavam à agricultura do café. Com o crescimento da área urbana, essas famílias viam a oportunidade de lotearem suas propriedades, convertendo terra rural em terra urbana. No momento atual, ocorre a junção desses proprietários fundiários à incorporadoras de centros maiores que implantam o padrão dos espaços residenciais fechados. Nesses últimos anos, verificou-se a instalação desses novos empreendimentos, mesmo em período de crise, ou em virtude 
deste, o investimento em bens imóveis, com menor desvalorização e maior tempo de circulação, proporcionam a retenção especulativa da terra urbana.

Observa-se que, em ambas as cidades, estão sendo implantados espaços residenciais fechados. Conforme apontado por Sposito e Góes (2013), esse tipo de empreendimento, implantado cada vez mais em áreas distantes e descontínuas do espaço urbano geral, causa a redefinição do conteúdo do que é periferia da cidade. Tais empreendimentos nas cidades estudadas se encontram nas zonas periféricas descontínuas e nas zonas periurbanas.

As condições de sítio urbano das duas cidades apresentam-se diferenciadas e também contribuem para as distintas morfologias da mancha urbana, Alfenas tem seu núcleo inicial de ocupação em um platô e a partir de suas encostas apresenta uma topografia variável de colinas cortadas por várias nascentes e vales de córregos. A própria expansão da cidade acompanhou um desses córregos, o Pedra Branca, na direção norte sul, reafirmada pelos dois principais acessos à cidade. Em Poços de Caldas, a Serra de São Domingos, ao norte, é um acidente topográfico limitador da expansão da mancha urbana nessa direção, o que contribui para a cidade apresentar uma disposição nas direções leste, oeste e sul, e mais recentemente, a sudoeste.

A partir do que foi exposto fica caracterizado a maior complexidade da estrutura urbana de Poços de Caldas do que a de Alfenas, assim como a polarização desta última pela primeira, como indica o último REGIC (IBGE, 2020a), em função da maior especialização e alcance de suas atividades econômicas, que determinam a posição hierárquica na rede urbana. É a partir dessa condição que Poços de Caldas polariza uma rede mais ampla e complexa de cidades pequenas e cidades médias, enquanto Alfenas polariza seu entorno de cidades pequenas (IBGE, 2020a).

\section{CONSIDERAÇÕES FINAIS}

$\mathrm{Na}$ análise comparativa entre as duas cidades, por se tratar de um modelo de estrutura urbana, deve-se considerar suas limitações e incorporar outras concepções a este, como afirma Villaça (2001), os modelos são bons pelo que eles podem sintetizar e não por um aprofundamento que eles possam oferecer. Nesse sentido, os modelos são úteis por oferecer uma síntese de características das cidades e, portanto, em possibilitar comparações. Cabe aos pesquisadores irem além deles, articulando uma fundamentação teórica que permita mais consistência às análises propostas, sobretudo, em uma teoria crítica, recuperar os processos de urbanização que deem conta de apreender as desigualdades socioespaciais das cidades capitalistas.

Se nenhuma das três maiores cidades médias da região (Poços de Caldas, Varginha e Pouso Alegre) evoluíram para uma cidade grande, longe disso, em função da posição na rede urbana, tributárias das três metrópoles da Região Sudeste, é válido pensar que Alfenas, como uma 
cidade média em consolidação, também tenha sua posição "travada" em decorrência do domínio destas três cidades no sul de Minas Gerais? A não ser que o atual momento de reestruturação produtiva e da rede urbana no país possibilite o salto de determinada cidade em função de potencialidades existentes, ascendendo sua posição na hierarquia urbana. Esta ao que parece não é a situação de Alfenas, pois não se verifica nenhum desenvolvimento econômico de um setor tecnológico ou estratégico no momento, embora mais pesquisas sejam necessárias.

A polarização que Alfenas exerce, com exceção do ensino superior com um alcance espacial maior, trata-se de uma polarização microrregional, principalmente na área da saúde. Enquanto Poços de Caldas apresenta uma complexidade maior de atividades mais qualificadas e de polarização regional maior.

Conforme exposto por Branquinho (2016), a localização de algumas cidades sul-mineiras junto à Rodovia Fernão Dias vem atraindo a desconcentração industrial das metrópoles para as cidades da região. Segundo o autor, fica evidente que a distribuição das indústrias ocorra de maneira seletiva, onde as cidades com melhores localizações, melhores infraestruturas e que apresentem políticas de subsídio sejam as escolhidas para os investimentos do setor industrial. Nesse contexto, a Rodovia impulsionou grande desenvolvimento econômico e urbano para as cidades em seu entroncamento, dentre elas, Pouso Alegre. Em contrapartida, devido a sua localização relativamente distante da Fernão Dias, Poços de Caldas não se aproveitou, de maneira direta, dos processos mencionados. Mesmo assim, em função das suas ofertas de comércios, serviços especializados e empregos, a cidade acaba polarizando uma elevada quantidade de cidades de menor porte do Sul de Minas e também exercendo influência em cidades localizadas no interior paulista.

Da análise realizada se depreende que a produção do espaço (e do tempo) das duas cidades encontram-se em estágios diferentes, o que, para além das diferenças quantitativas, resulta em relações socioespaciais qualitativamente distintas, em práticas cotidianas distintas, com percepções de tempo e espaço diferenciadas, como nos tempos de deslocamentos da população, no trânsito e engarrafamentos que se fazem notar nas áreas centrais de Poços de Caldas.

Observa-se que os processos de autossegregação em ambas as cidades são recentes, iniciando-se entre as últimas décadas do século XX e início do século XXI. Por seu turno, o turismo em Poços de Caldas deve ser levado em consideração, refletindo diversos serviços voltados ao setor turístico e na valorização dos espaços centrais, o que tende a expulsar atividades voltadas a população de menor poder aquisitivo para áreas mais distantes do centro, definindo setores espaciais dentro da mancha urbana. Em Alfenas, esses processos de reestruturação e refuncionalização ainda são incipientes. 
Alfenas, apesar da formação de alguns centros locais de comércio, ainda mantém sua centralidade principal em seu centro tradicional. O que se diferencia do caso de Poços de Caldas, considerando suas dimensões demográficas e espaciais mais amplas, verifica-se a formação de novas centralidades. A pressão do crescimento econômico e populacional tem levado à ocupação das franjas da cidade, valorizando esses espaços e empurrando tanto os segmentos mais pobres da população quanto a atividade agrícola para locais mais distantes.

\section{REFERÊNCIAS}

ALFENAS, Prefeitura Municipal de. Leitura técnica do Plano Diretor de Alfenas. Alfenas: 2006.

AMORIM FILHO, O. B.; SENA FILHO, N. A morfologia das cidades médias. Goiânia: Ed. Vieira, 2007. 200p.

ANDRADE, A. C. Pouso Alegre (MG): expansão urbana e dinâmicas socioespaciais em uma cidade média. 2014. 300 f. Tese (Doutorado em Geografia) - Instituto de Geociências e Ciências Exatas, Universidade Estadual Júlio de Mesquita Filho, Rio Claro, 2014.

ANDRADE, A. C. Paisagem e Qualidade de Vida em Localidades Turísticas: O Caso de Poços de Caldas, Minas Gerais, Brasil. 2005. 202 f. Dissertação (Mestrado em Geografia) - Instituto de Geociências e Ciências Exatas, Universidade Estadual Júlio de Mesquita Filho, Rio Claro, 2005.

AZAIS, C. Comparando cidades desigualmente desenvolvidas: Santo André (São Paulo, Brasil) e Saint-Denis (Île de France, França). In: SPOSITO, E. S. (Org.). Cidades médias: produção do espaço urbano e regional. São Paulo: Expressão Popular, 2006, p. 305-325.

BRANQUINHO, E. S. (Org.). A produção do espaço segregado em Alfenas-MG. Alfenas: Ed. Universidade Federal de Alfenas, 2021. 326p.

BRANQUINHO, E. S. A reestruturação das cidades médias no sul de Minas Gerais. In: ENCONTRO NACIONAL DE GEÓGRAFOS. 18., 2016, São Luís. Anais... São Luís, 2016.

CORREAA, R. L. Construindo o conceito de cidade média. In: SPOSITO, M. E. B. (Org.). Cidades médias: espaços em transição. São Paulo: Expressão Popular, 2007, p. 23-33.

CORREAA, R. L. Estudos sobre a rede urbana. Rio de Janeiro: Bertrand Brasil, 2006. 336p.

GEIGER, P. P.; DAVIDOVICH, F. Aspectos do fato urbano no Brasil. Revista Brasileira de Geografia, v. 23, n. 2. p. 263-362, 1961.

INSTITUTO BRASILEIRO DE GEOGRAFIA E ESTATÍSTICA (IBGE). Regiões de Influência de Cidades de 2018 (REGIC). Rio de Janeiro: IBGE, 2020a.

INSTITUTO BRASILEIRO DE GEOGRAFIA E ESTATÍSTICA (IBGE). - Estimativas da População 2020. Disponível em: https://www.ibge.gov.br/estatisticas/sociais/populacao/9103estimativas-de-populacao.html $?=\& \mathrm{t}=$ o-que-e. Acesso em: 10 out. $2020 \mathrm{~b}$. 
INSTITUTO BRASILEIRO DE GEOGRAFIA E ESTATÍSTICA (IBGE). Produto Interno Bruto dos municípios de 2017. Disponível em: https:/www.ibge.gov.br/estatisticas/economicas/contasnacionais/9088-produto-interno-bruto-dos-municipios.html? $=\& \mathrm{t}=\mathrm{o}$-que-e. Acesso em: 12 ago. 2020c.

INSTITUTO BRASILEIRO DE GEOGRAFIA E ESTATÍSTICA (IBGE). Estatísticas do Cadastro Central de Empresas (CEMPRE) de 2018. 2018. Disponível em: https://www.ibge.gov.br/estatisticas/economicas/comercio/9016-estatisticas-do-cadastro-central-deempresas.html? $=\& \mathrm{t}=$ o-que-e. Acesso em: 16 ago. 2020

INSTITUTO BRASILEIRO DE GEOGRAFIA E ESTATÍSTICA (IBGE). Censo demográfico de 2010: resultados. 2010. Disponível em: https://censo2010.ibge.gov.br/resultados.html. Acesso em: 8 dez. 2020.

INSTITUTO BRASILEIRO DE GEOGRAFIA E ESTATÍSTICA (IBGE). Regiões de influência das cidades de 2007 (REGIC). Rio de Janeiro: IBGE, 2008.

LEFEBVRE, H. Espaço e política: o direito à cidade II. São Paulo: Humanitas, 2016. 192p.

LEFEBVRE, H. O direito à cidade. Trad. FRIAS, R. E. (Le Droit à la Ville, Paris: An, 1968). 5. ed. São Paulo: Centauro, 2008. 5. 144p.

LEFEBVRE, H. Sociologia de Marx. Rio de Janeiro: Forense-Universitária, 1979. 176p.

LENCIONI, S. Reestruturação urbano-industrial: centralização do capital e desconcentração da metrópole de São Paulo: a indústria têxtil. 1991. 287 f. Tese (Doutorado em Geografia Humana), Faculdade de Filosofia Letras e Ciências Humanas, Universidade de São Paulo, São Paulo, 1991.

MARRAS, S. A propósito de águas virtuosas. Formação e ocorrência de uma estação balneária no Brasil. Belo Horizonte: UFMG, 2004. 479p.

MEgale, N. B. Memórias históricas de Poços de Caldas. Sulminas, 1990. 235p.

OLIVEIRA, E. M. Dinâmica locacional das indústrias e a produção do espaço urbano em Poços de Caldas (MG). 2012. 177 f. Dissertação (Mestrado em Geografia) - Instituto de Geociências e Ciências Exatas, Universidade Estadual Júlio de Mesquita Filho, Rio Claro, 2012.

PPGCEM UNIFAL-MG. Programa de Pós-graduação em Ciência e Engenharia de Materiais. Disponível em: https://www.unifal-mg.edu.br/ppgcemateriais/node/11. Acesso em: 20 nov. 2019.

SEGUSO, M. Os admiráveis italianos de Poços de Caldas: 1884-1915. 3. ed. Poços de Caldas: Ed. Autor, 207. 183p.

SILVA, E. A. (Re)produção do espaço urbano e segregação socioespacial em Poços de Caldas, Minas Gerais. 2021. 211 f. Dissertação (Mestrado em Geografia) - Universidade Federal de Alfenas, Alfenas, 2021.

SPOSITO, M. E. B. A produção do espaço urbano: escalas, diferenças e desigualdades socioespaciais. In: CARLOS, A. F. A.; SOUZA, M. L.; SPOSITO, M. E. B. (Orgs). A produção do espaço urbano: agentes e processos, escalas e desafios. São Paulo: Contexto, 2011, p. 123-145. 
SPOSITO, M. E. B. Cidades Médias: reestruturação das cidades e reestruturação urbana. In: SPOSITO, M. E. B. (Org.) Cidades médias: espaços em transição. São Paulo: Expressão Popular, 2007, p. 233-253.

SPOSITO, M. E. B.; GÓES, E. M. Espaços fechados e cidades: insegurança urbana e fragmentação socioespacial. 1. ed. São Paulo: Editora Unesp, 2013. 376p.

VILLAÇA, F. Espaço intra-urbano no Brasil. São Paulo: Studio Nobel, 2001. 373p. 